KRZYSZTOF ANTCZAK

Uniwersytet im. Adama Mickiewicza

DAN TUDOR IONESCU

Universitatea din Bucureşti
Images

vol. XVII/no. 26

Poznań 2015

ISSN 1731-45Ox

\title{
Reading Plutarch of Chaeronea: A Cinematic Portrait of the Youth of Alexander the Great as Envisaged by Robert Rossen and Oliver Stone
}

We live in a world suffused with images, in which people increasingly derive their notions of the past from audiovisual media.[1] Historical film, and even less biographical film, are not limited exclusively to the cinema of genres.[2] After all, the definition of a biographical film encompasses both fact and fiction: it is a tale about the life and activities of a person recorded on the pages of history.[3] In the words of Marek Hendrykowski, "Cinematographic biography is a picture spanning the reality of one's life on the one hand, and the convention-like nature of a symbolic representation which is accessible to our senses and yields to various interpretations." [4] Hendrykowski has chosen to call this arrangement "biographical suspense." [5] Unlike historiography, the film remains in an intact form; it is not revised - the creator of the cinematic biography selects facts from the life of a historic figure, choosing those which correspond to his or her vision of a given protagonist.[6] This is because film is not a legitimate form of scientific discourse.[7] In a broader context, we are dealing with the relationship between historiography and historiophoty. [8]

[1] R.A. Rosenstone, "History in Image/History in Words. Reflections on the Possibility of Really Putting History into Film", The American Historical Review 1988, no. 5, pp. 1173-1185.

[2] M. Hendrykowski, Film jako źródło historyczne, Ars Nova, Poznań 2000; Idem, "Historyczny film", [in:] Idem, Leksykon gatunków filmowych, SF "Montevideo", Wrocław 2001, pp. 74-77; Idem, "Biograficzny film", ibid., pp. 19-20; Idem, "Biografizm jako dążenie kina współczesnego", [in:] Biografistyka filmowa. Ekranowe interpretacje losów i faktów, ed. T. Szczepański, S. Kołos, Wydawnictwo Adam Marszałek, Toruń 2007, pp.18-19; J. Wojnicka, "Film historyczny", [in:] J. Wojnicka, O. Katafiasz, Stownik wiedzy o filmie, Wydawnictwo Szkolne PWN, Warszawa 2009, pp. 369373; P. Litka, "Historyczny film", [in:] Encyklopedia kina, ed. T. Lubelski, „Biały Kruk”, Kraków 2010, pp. 415-416; O. Katafiasz, "Biograficzny film”, ibid., p. 106.
[3] B. Michałek, "Filmowa biografia - dziś", Kino 1974, no. 9, pp. 58-59; J. Płażewski, "Kryzys w branży biografów”, Kino 1993, pp. 28-29; K. Giedrys, "Fakty mniej autentyczne", Kino 2006, no. 7/8, pp. 40-42; M. Hendrykowski, "Film biograficzny", Film 1998, no. 5, p. 141; Idem, "Biografizm w kinie współczesnym", Kwartalnik filmowy 2007, no. 59, pp. 66-79. [4] M. Hendrykowski, Biografizm jako dążenie kina współczesnego, pp. 14-15.

[5] Ibid., p. 15.

[6] M. Ferro, Kino i historia, trans. T. Falkowski, Wydawnictwo Naukowe PWN, Warszawa 2011, p. 214. [7] W. Guynn, Writing History in Film, Routledge, New York 2006.

[8] H. White, "Historiography and historiophoty", The American Historical Review 1988, no. 5, pp. 1193-1199. 
The cinematographic representation of a protagonist, which has its counterpart in the reality outside the screen, becomes a relation between a notion and reality. A biographical film ensures the viewers that there is a real person behind the history of a life they are watching. In this sense, a film biography possesses an empirical dimension. Undoubtedly, a film biography is dependent on facts from the life of a given individual. However, these details are hidden in historical sources, while the latter are subject to constant (re)interpretation. A historian (re)constructs the past from sources based on a methodology. It is from such historical sources that a vision of the past is derived. [9] Therefore, the basis of both historiography and historiophoty are historical sources. The issue we would like to address here is whether and to what extent Robert Rossen's Alexander The Great (1956) and Oliver Stone's Alexan$\operatorname{der}(2004)$ reflects the literary vision of Alexander's youth presented in Life of Alexander by Plutarch of Chaeronea. The object of scrutiny here is two historical-biographical films from two different periods in the history of cinema.[10] The analysis will focus not so much on the reception of ancient history, but rather on ancient literary sources in an attempt to assess the extent to which Rossen's and Stone's cinematic works convey the literary vision of the youth of Alexander the Great presented by Plutarch of Chaeronea. In other words, our goal is to determine whether these film biographies are "suspended" between historical sources that enable a reconstruction of Alexander's life and an on-screen representation offering multiple interpretations.

We should mention another film from the history of modern cinematography: the interpretation of the larger-than-life heroic character of Alexander the Great in the Bollywood Indian film Sikandar or Sikander from 1941, directed by Sohrab Modi, who also played the part of King Puru/Porus in film, while Sikander/Sikandar i.e. Alexander of Macedon is played by no other than Prithviraj Kapoor. This film must be seen through the lenses of the Indian patriotic movement for freedom from British Raj/British Rule, which was rooted in the idea of Indian autonomy and later independence or Swaraj/Self-Rule. It is also a war film produced in the tragic times of World War II, when many Indian soldiers served, fought, and died for the British Empire.[11]

The relationship between the text of Plutarch, i.e. a historical source (written, literary, narrative) and the works of Rossen and Stone is the relation between written culture and the currently predominant audiovisual culture. The matter under consideration is not the adapta-

[9] J. Topolski, Metodologia historii, PWN, Warszawa 1973; Idem, Wprowadzenie do historii, Wydawnictwo Poznańskie, Poznań 2001; Idem, Jak się pisze i rozumie historię. Tajemnice narracji historycznej, Wydawnictwo Poznańskie, Poznań 2008; H.I. Marrou, O poznaniu historycznym, trans. H. Łaszkiewicz, Wydawnictwo Marek Derewiecki, Kęty 2011, pp. 78-101. [10] M. Ferro, op. cit., p. 213.
[11] A.G. Dumitru, "De la jocul de-a Alexandru la a-1 juca pe Alexandru și înapoi" = "From playing Alexander to the play about Alexander, and back again", [in:] National Conference from Bucharest, 28-29 November 2014: Alexandru Macedon: Istorie, Imagine, Interpretare $=$ Alexander of Macedon: History, Image, Interpretation, [in print]. 
tion of a literary work,[12] but the presence of historical sources in the analysed films and their interpretation. Undoubtedly, in the work of a filmmaker, a written, literary or narrative historical source becomes not so much the basis for the film, but an invisible inspiration.

The starting point here is the figure of Alexander III of Macedon (356-323 BC), king of Macedonia from the Argead dynasty, who went down in history as an unsurpassed visionary, and one of the world's most brilliant strategists and conquerors. [13] It should be stressed that the legend of Alexander the Great has been built since the Antiquity - by means of literary portrayals written by Alexander's historians - Callisthenes of Olynthus, Onesicritus of Astypalaia, and Ptolemy, son of Lagos and founder of the Lagid dynasty;[14] scholars from the Roman Empire - Diodorus of Sicily,[15] Plutarch of Chaeronea, and Flavius Arrianus; [16] and visual representations by Lysippus, Leochares, Apelles, Pyrgoteles, and Philoxenus of Eretria.[17]

There were also other important contemporary or almost contemporary historians and chroniclers of Alexander's deeds and reign: we can include here Aristobulus of Cassandreia, who was the second main source for Arrian's Anabasis Alexandri, and other figures, like Eumenes of Cardia, Hieronymus of Cardia, Diodorus of Erythreia, Nearchus of Crete, Chares of Mytilene, Polycleitus of Larissa, and Cleitarchus of Olynthus, to name only a few of the Macedonian's early historians. Perhaps equally important as those quoted above were Callisthenes, Onesicritus, and Ptolemy. They were all (and other less known figures, such as Anaximenes of Lampsacus, Marsyas of Pella, and Strattis of Olynthus) instrumental, although from their writings only small and scattered fragments survived in subsequent historical works in Greek and Latin by authors from the Roman Imperial age: we are thinking here mainly of Cleitarchus, whose history of Alexander's exploits and deeds of arms influenced numerous authors and works as varied as Diodorus' Bibliotheca Historica Liber XVII, Q. Curtius Rufus' De rebus gestis Alexandri Magni regis Macedonum, Trogus Pompeius-Justin's Historiae Philippicae Liber XII, and even Plutarch's Vita Alexandri, and the Pseudo-Callisthenes' Historia Alexandri Magni, better known to us as the Greek Romance of Alexander of Macedon (or the Greek Romance of Alexander the Great), which was a novel of legends and tales about the Macedonian conqueror, seen more as

[12] M. Hendrykowski, Współczesna adaptacja filmowa, Wydawnictwo Naukowe UAM, Poznań 2014.

[13] P. Green, Aleksander Wielki. Biografia, Warszawa 2001; R. Lane Fox, Alexander the Great, Allen Lane, London 1973; A. Suceveanu, Alexandru cel Mare, Academiei Române, București 1993; N.G.L. Hammond, Alexander the Great: King, Commander, and Statesman, Bristol Classical Press, London 1994; K. Nawotka, Aleksander Wielki, Wydawnictwo UWr, Wrocław 2007.
[14] R. Turasiewicz, "Historiografia hellenistyczna”, [in:] Literatura Grecji starożytnej, vol. 2: Proza historyczna, krasomówstwo, filozofia i nauka, literata chrześcijańska, ed. H. Podbielski, Towarzystwo Naukowe KUL, Lublin 2005, pp. 63-87.

[15] K. Korus, "Historiografia okresu Cesarstwa", [in:] Literatura Grecji starożytnej, vol. 2, pp. 97-99.

[16] Ibid., pp. 105-109.

[17] M. Nowicka, Twarze antyku, „Czytelnik”, Warszawa 2000 , pp. 58-72. 
a mythical-epic hero than as a true historical character. The Pseudo-Callisthenes' Greek Romance of Alexander the Great was written in Alexandria, most probably some time between the $3^{\text {rd }}$ century BC and the $2^{\text {nd }}$ or $3^{\text {rd }}$ century $A D$, and was later translated into the languages of many countries, [18] from Iceland and Scandinavia to Spain and Italy, from the British Isles to the Balkans and Russia, and from Egypt and Ethiopia to Mongolia and Malaysia.[19]

The author we are most interested in, Plutarch of Chaeronea (50-120 AD),[20] was one of the most prolific and most readily read authors of Antiquity.[21] This comprehensively educated Greek from Chaeronea was a propagator of philosophy and biography,[22] although the biographies he wrote certainly do not meet the requirements of historical or scientific biography. Parallel Lives from the early $2^{\text {nd }}$ century $\mathrm{AD}$, which includes Alexander's biography, was written in a didactic spirit, and was intended to serve as a moral incentive through its depictions of characters and vivid images of their actions and virtues, provide an impulse for emulation and discourage errors. Plutarch emphasized that he did not aspire to be a historian, and that he did not aim to compete with historians. In Life of Alexander, he observes that he is not writing a history but a biography; the work does not relate facts, but events which demonstrate Alexander's virtues and vices. Furthermore, he notes that his approach to biographical writing is more akin to the work of a painter,[23] as he is interested in personalities and characters rather than historic figures' partaking in a broader historical process, [24] although as an author he perceived the significance of Alexander's achievements for world history.[25]

Plutarch enjoyed high esteem among his contemporaries,[26] and his oeuvre became part of the heritage of European civilisation, leaving its mark on educational, ethical, and political thought. In Western Europe, Plutarch was rediscovered in the $14^{\text {th }}$ and $15^{\text {th }}$ centuries, while the $16^{\text {th }}$ and $17^{\text {th }}$ centuries marked the peak of his popularity.[27] He was avidly read by thinkers, scholars, artists, and politicians, including Leonardo Bruni, Philip Melanchton, Montaigne, Henry II, III, and

[18] Pseudo-Callisthenes, Historia Alexandri Magni, trans. K. Nawotka, Wydawnictwo Naukowe UAM, Poznań 2010.

[19] A. Suceveanu, op. cit., pp. 14-25.

[20] K. Ziegler, Plutarchos 2, Real Encyklopedie 21.1, 1951, col. 636-962; D.A. Russell, Plutarch, Duckworth, London 1973; T. Sinko, Literatura grecka 3.1., Literatura grecka za Cesarstwa Rzymskiego (wiek I-III n.e.), PAU, Kraków 1951, pp. 194-267; R. Flacelière, Historia literatury greckiej, "Antyk", Kęty 2004, pp. 427-434; K. Korus, "Plutarch z Cheronei", [in:] Literatura Grecji starożytnej, vol. 2, pp. 241-269.

[21] K. Nawotka, "Plutarch i jego dzieło", [in:] Plutarch, O szczęściu czy dzielności Aleksandra, trans.

K. Nawotka, Wydawnictwo UWr, Wrocław 2003, p. 14.
[22] Ibid., p. 15.

[23] Plutarch, Alexander 1.3 [Plutarch, Alexander, [in:] Plutarch's Lives VII: Demosthenes and Cicero, Alexander and Caesar, trans. B. Perrin, Harvard University Press, Cambridge-London 1967, pp. 223-439]; T. Sinko, op. cit., p. 242; K. Korus, Plutarch $z$ Cheronei, pp. 262-263.

[24] T. Sinko, op. cit., p. 242; K. Nawotka, "Plutarch i jego dzieło", p. 32.

[25] K. Nawotka, "Plutarch i jego dzieło", p. 33.

[26] Ibid., p. 16.

[27] R. Flacelière, op. cit., p. 432-433; K. Nawotka, "Plutarch i jego dzieło", pp. 17-18. 
IV. He also proved to be a highly significant author for Shakespeare, Bacon, Rousseau and Emerson. [28]

It should be noted that the first American blockbuster film portraying the ruler of Macedonia was not made until the 1950 . The 1950 s and 1960s, when Rossen's Alexander the Great was made, was a period of competition between cinema and television. The film industry opted for the formula of monumental spectacle, made in colour using the Cinemascope technique and filmed with tremendous grandeur using magnificent set decorations, crowds of extras, and a star-studded cast. Filmmakers sought to make films as unlike a TV broadcast as possible. Bible-based and historical cinema enjoyed particular interest among audiences. In these productions, the boundary dividing history and adventure became considerably blurred. Films with biblical themes included such titles as Samson and Delilah (1949) and, The Ten Commandments (1956) by Cecil B. DeMille, Demetrius and the Gladiators (1954) by Celmer Daves, and The Prodigal (1954) by Richard Trope. In turn, major historical productions of that period include Ben Hur (1959) by William Wyler, The Egyptian (1954) by Michael Curtis, Land of Pharaohs (1955) by Howard Hawks, Helen of Troy (1956) by R. Wise, and Joseph Mankiewicz's screen adaptation of Shakespeare's Julius Cesar (1953). These films usually featured major actors of the times, like Charlton Heston, Victor Mature and Richard Burton.[29]

The first to confront the legend of Alexander the Great was Robert Rossen (1908-1966). This American director and screenwriter began his film career in the 1940 s with a very well received work about a boxer's career, entitled Body and Soul (1949), and ended with a study in psychopathology - Lilith (1964). Rossen's achieved genuine success with All the King's Men (1949), showing the mechanisms of a political career, and The Hustler (1961) with Paul Newman.[30] In his analysis of Rossen's work, Alan Casty observed:

In all of his major works Rossen was concerned with the search of a young man for something which he does not recognize as himself, his identity. He is a character of a certain natural inner force (for which charisma, despite its over-use, is still a good word), but he cannot fully identify or control this energy, skill, or potential, this source of grace and power.[31]

[28] M. Brożek, "Wstęp", [in:] Plutarch z Cheronei, Żywoty sławnych mężów, vol. 1, trans. and ed. M. Brożek, Ossolineum, "De Agostini”, Wrocław 2004, pp. 67-72 (LXVII-LXXII).

[29] J. Toeplitz, Nowy film amerykański, WAiF, Warszawa 1973, pp. 33-6o; R. Marszałek, Filmowa pop-historia, Wydawnictwo Literackie, Kraków 1984, pp. 129-131, 140-141; J. Wojnicka, op. cit., p. 372; J. Paul, "Oliver Stone's Alexander and Cinematic Epic Tradition", [in:] Responses to Oliver Stone's Alexander. Film, History, and Cultural Studies, ed. P. Cartledge, F.R. Greenland, The University of Wisconsin
Press, London 2010, p. 23; Ł. Plesnar, R. Syska, "Amerykańskie kino lat 50.: złota dekada", [in:] Historia kina, vol. 2. Kino klasyczne, ed. T. Lubelski, I. Sowińska, R. Syska, Universitas, Kraków 2011, pp. $815-817$.

[30] Z. Pitera, "Rossen R.", [in:] Idem, Leksykon reżyserów filmowych. Reżyserzy zagraniczni, WAiF, Warszawa 1978, p. 164; Ł. Plesnar, "Rossen Robert", [in:] Encyklopedia kina, p. 845. [31] A. Casty, "The Films of Robert Rossen", Film Quarterly 1966-1967, vol. 20, no. 2, p. 3. 
Rossen's cinematic portrayal of Alexander the Great certainly tallies with this concept.[32] He shows the military and political conquests of the soldier-king, and the romantic heroizing of the man.[33]

As regards the other director discussed here, i.e. Oliver Stone, biographies occupy a significant place in his work. He is perhaps the most 'historical' of American film directors. [34] Approaching history in all possible ways and modes, Stone has made pictures telling the story of a number of figures from contemporary U.S. history, including both major protagonists like J.F. Kennedy, Richard Nixon, Fidel Castro, and Jim Morrison, as well as the less known Ron Kovic, a Vietnam veteran, or Le Ly Hayslip, a Vietnamese woman suffering from the aftermaths of war.[35] Robert A. Rosenstone concluded: "Maybe Oliver Stone is a kind of griot for a new visual age. He is in a sense making history by making myths: making myths by wanting to tell Truths; wanting the myths he recounts to have a truth value." [36]

Alexander was made during a period (which began in the 1990s) when new technologies were introducing hyperrealism to cinema. CGI was given a prominent place in representations of historic events. There are films in which special effects proved to be a necessary addition, but did not constitute the essence of the film. Computer graphics proved helpful in reconstructing the historic setting of great events, adding to the visual dimension. With Ridley Scott's Gladiator (2000) came a revival of the cinematic epic about the ancient world.[37] It is worth noting that the same year as Stone's Alexander, the audience saw the premieres of Troy by W. Petersen and The Passion of the Christ by M. Gibson. The growing interest among $21^{\text {st }}$-century filmmakers in Antiquity is also manifested in the fact that Stone was not the only one interested in adapting the story of Alexander's life to the screen: Baz

[32] Ibid., p. 7: "In 1956 he [R. Rossen] released Alexander the Great, a historical and technicolored epic that (unlike any-thing he had done previously) was hopefully intended as a commercial blockbuster, but was nonetheless still intended as a further depiction of the young man of power, energy, and will and the symbols to which he applies them. On the political level Alexander seeks by his conquests to fulfill the righteous political destiny of his nation, and one can see, in the destruction he spreads, Rossen's comment on the political power struggles of the modern world. On the personal level Alexander is portrayed as driven by his lust for glory"; cf. R. Marszałek, op. cit., p. 141.

[33] K. Shahsbudin, "The Appearance of History: Robert Rossens's Alexander The Great", [in:] Responses to Oliver Stone's Alexander, p. 103; A. Prieto, B. Antela, "Alejandro en el cine", [in:] Imagines. La Antigüedad en las artes escénicas y visuales, ed. J.M. Castillo Pascual, Universidad de La Rioja, Logroño 2008, pp. 263-279.
[34] A. Chaniotis, "Making Alexander Fit for the Twenty-first Century Oliver Stone's Alexander", [in:] Hellas on Screen: Cinematic Receptions of Ancient Literature, Myth and History, eds I. Berti, M. García Morillo, Steiner, Stuttgart 2008, p. 196.

[35] S. Mackey-Kallis, Oliver Stone's America, Westview/Harper Collins, New York 1996; R. Rosenstone, "Oliver Stone as Historian", [in:] Oliver Stone's USA: Film, History, and Controversy, ed. R. Toplin, University Press of Kansas, Kansas 2000, pp. 26-39= "Oliver Stone jako historyk", [in:] Świat $z$ historia, ed. P. Witek, M. Woźniak, Wydawnictwo UMCS, Lublin 2010, pp. 13-26 [transl. P. Witek]; K. Loska, "Stone Oliver", [in:] Encyklopedia kina, pp. 927-928.

[36] R. Rosenstone, Oliver Stone as Historian, p. 38-39.

[37] A. Elliott, "Introduction: The Return of the Epic", [in:] The Return of the Epic Film: Genre, Aesthetics, and History in the $21^{\text {st }}$ Century, ed. A.B.R. Elliott, Edinburgh University Press, Edinburgh 2014, pp. 1-16; J. Paul, op. cit., pp. 15-16. 
Luhrmann, known for Romeo + Juliet (1996) and Moulin Rouge! (2001) also considered such a project. In Luhrmann's picture, Alexander was to be played by Leonardo DiCaprio.[38]

Oliver Stone, inspired by Alexander the Great's biography by Robin Lane Fox, claimed that he sought to achieve a credible depiction of the protagonists, leading him to invite a historian from Oxford University to collaboration. [39] About Alexander Oliver Stone said: "This is not a documentary. It is a dramatization, though it should take history as its starting point." [40]

The ancients believed that the birth of a child who would become a great historical figure was accompanied by signs, auguries, and extraordinary and curious events. Plutarch of Chaeronea reports of Alexander's mother, Olympias, that a fiery lightning entered her in the wedding chamber.[41] This fiery lightning was Zeus, who thus beat Philip II to Olympias and impregnated her first, by virtue of which Alexander could be pronounced Zeus' son. Meanwhile, Philip II saw in a dream seals showing a lion engraved in the bosom of his wife, which was to presage the extraordinary, lion-like nature of their son. [42] Plutarch also claims that on the night that Alexander was conceived, Philip saw Olympias having intercourse with a giant snake, an incarnation of the deity Ammon of Siwah (an oasis in the Libyan Desert). This is a vivid, literary depiction of the divine conception of Alexander. An allusion to divine origins is also found in the subsequent part of Plutarch's work. Quoting Eratosthenes, the Chaeronean observes that when bidding Alexander farewell before his expedition, Olympias revealed to him the secret of his coming into the world, calling upon him to be brave as befit his birth.[43]

Ancient authors were very fond of synchrony. Plutarch states that Alexander was born on the same night a fire destroyed the temple of Artemis in Ephesus. This goddess assisted with Alexander's birth in Pella. Furthermore, Plutarch notes that on the day the city of Potidea was captured, Philip received news of the defeat of the Illyrians by his commander Parmenion, of a horse-racing victory in Olympia, and of the birth of his son Alexander.[44] All these omina, or good portents, foretold the birth of an invincible son.[45]

[38] A. Gortatowicz, "Sezon na Aleksandra", Film 2003, 02, p. 26; Eadem, "Wojownik i kochanek", Film 2004, 09, p. 10-12.

[39] R. Lane Fox, The Making of "Alexander": The Official Guide to the Epic Alexander Film, R\&L Publ., London 2004.

[40] Ibid., p. 31.

[41] Plutarch, Alexander 2.2: "Well, then, the night before that on which the marriage was consummated, the bride dreamed that there was a peal of thunder and that a thunder-bolt fell upon her womb, and

\section{The birth of Alexander}


Plutarch does not say much about Alexander's mother, Olympias. We learn that she was the daughter of Neoptolemus, son of Achilles; that she worshipped Dionysius and participated in Orphic rites and Dionysian orgies; and that she was surrounded by tamed snakes. The latter company, according to Plutarch, weakened her bonds with her husband.[46] He observes that Philip, when still a young man, fell in love with Olympias during the mysteries.[47] Plutarch devotes equally little attention to Philip. He highlights his origins, i.e. his Heraclid descent, $[48]$ notes that he lost an eye while peeping through a crack in the door as Olympias shared her bed with the god Ammon in the shape of a snake.[49]

Robert Rossen focused on outlining the historical background of Alexander's birth,[50] portraying the situation in Greece during the Macedonian expansion, the rivalries between Greek factions, and the speeches of Aeschines and Demostenes. Through their orations, we learn about the corruption, methods, and schemes of Philip II and the siege of Olynthus. The director vividly presented the burning of the temple of Artemis in Ephesus and the arrival of a messenger from Pella to Philip, encamped near Olynthus, to inform the Macedonian king that a son named Alexander had been born to him. The dialogue between Philip and the messenger provides information about Alexander's divine origins.

In the scene depicting the arrival of Philip in Pella, Rossen shows the meeting of Alexander's parents. In another dialogue scene, they talk about the baby over its crib, referring to Alexander as a "little lion" and "little god." Rossen wove in the theme of an augur interpreting the portents that accompanied Alexander's birth - a storm, a shooting star, two eagles, the burning down of the temple of Artemis in Ephesus - which were to confirm his divine descent. Historical research has demonstrated that on the day of Alexander's birth, Philip was 27 years old, while the actor playing Philip, Fredric March, was made up as a 40-year-old, impetuous king obsessed with the fear of losing power. Rossen's depictions and dialogues bombard the viewer with a tremendous amount of historical facts; the director does not depart from Plutarch's account, but selects from it and shapes it with skill.

Alexander by Oliver Stone begins with a metaphorical depiction of Alexander's death in Babylon in $323 \mathrm{BC}$, and the issue of succession after the demise of the Macedonian king - an event which in actual fact marked the beginning of over four decades of armed strife for power over the Empire created by Alexander. The plot subsequently

[46] Plutarch, Alexander 2; E.D. Carney, "Olympias and Oliver: Sex Sexual Stereotyping and Women in Oliver Stone's Alexander", [in:] Responses to Oliver Stone's Alexandero, pp. 137-138.

[47] Plutarch, Alexander 2.

[48] Ibid..

[49] Ibid. 3.1: "He [Philip] was to lose that one of his eyes which he had applied to the chink in the door when he espied the god, in the form of a serpent, sharing the couch of his wife"; E.D. Carney, op. cit., pp. $137-138$.

[50] K. Shahsbudin, "The Appearance of History: Robert Rossens's Alexander The Great", [in:] Responses to Oliver Stone's Alexander, pp. 92-93. 
moves to Egyptian Alexandria, where one of the successors to Alexander's heritage begins the tale of his companion-ruler. The person in question is Ptolemy, son of Lagos, the satrap of Egypt and founder of the Lagid dynasty. [51] This character is key to the interpretation of the figure of Alexander in Stone's portrayal. Ptolemy was Alexander's companion, a military man, and the author of a work which did not survive, but which had been written in an objective and matter-offact manner, as noted by Flavius Arrianus. [52] Ptolemy relied on staff diaries and his own memories. The work of Ptolemy was free from fantasy and rhetoric, providing instead mere facts in a concise, simple style.[53]

The cinematic portrayal of Alexander in Stone's picture is a subjective narrative.[54] The tale of Alexander is told from the viewpoint of a general and trusted confidant of Alexander. He engages in a kind of retrospection, returning to Ptolemy's lost historical narrative. With this introduction, Stone goes beyond a factual narrative. In other words, he resurrects lost historical sources in a cinematic form. Like Plutarch, he intends to spin a subjective vision of Alexander's fate. The birth of Alexander is recounted by Ptolemy, who resorts merely to dry facts.

The story then moves to Pella, the capital of Macedonia. Quoting unidentified sources, Ptolemy states that some considered Olympias a witch and that Alexander was fathered by Dionysius or Zeus. This is a starting point for the outline of Alexander's personality. Stone omits the motif of Alexander's birth. In a darkened bedroom, he shows Olympias surrounded by snakes, trying to demonstrate the beauty of the reptiles to little Alexander. The mother nurtures an awareness of the divine descent of her son, calling him "little Achilles." Stone's Olympias is a devoted worshipper of Dionysius, who criticizes the intemperance of her husband. Meanwhile, Philip II is a one-eyed, possessive drunkard who seeks to make her bend to his will, threatening her with death. During a row, he calls her a "proud bitch", a "whore", and a "bitch from Hades." The scene ends with Philip running away from a mass of snakes, shouting "Damn your sorceress soul!" Young Alexander stands to defend his mother, while Olympias shouts "In my womb, I carried my avenger!" Unlike Rossen, Stone does not flood the viewer with facts, i.e. the historical background, focusing instead on the emotional element, showing the psychological structure of relationships between Philip, Olympias, and Alexander. Stone has a tendency to demonize Olympias and Philip's cunningness and ambitions.

[51] R. Turasiewicz, op. cit., p. 65; R. Lane Fox, "The Making of Alexander", p. 22.

[52] Arrianus 4, 14.

[53] R. Turasiewicz, op. cit., p. 65.

[54] In the first scene Ptolemy say: “'Tyrant”, they yell so easily. I laugh. No tyrant ever gave so much. What do they know of the world, these schoolboys? It takes strong men to rule [...] Did such a man as 'Alexander' exist? Of course not. We idolize him, make him better than he was." This is a vindication of Alexander. Ptolemy is defending Alexander's autocratic rule; A. Chaniotis, op. cit., pp. 188-189. 
Alexander's youth

The surviving ancient sources devote surprisingly little attention to Alexander's childhood; the information on the first 13 years of his life is anecdotal - preserved nowhere else but in Plutarch's account. The episodes from the life of young Alexander were obviously aimed at showing his character traits. [55] Plutarch does not mention anything about the relationships between the young Alexander and Olympias. A theory which is widely advanced, namely that as a child Alexander remained under his mother's care, thus ascribing to her substantial influence on the son, and accounting for the son-father rivalry, is only speculation.[56]

As regards Alexander's upbringing and education, Plutarch recounts that at home he was surrounded by numerous caretakers, tutors, and teachers. One of those was Leonidas, a relative of his mother, and a man of stern approach. His strictness is also mentioned by the Chaeronean in connection with Alexander's expeditions, specifically, when describing the siege of Gaza.[57] Another tutor was Lysimachus of Acarnania, of whom Plutarch speaks in critical terms.[58]

Plutarch devotes most attention to the most eminent teacher of Alexander - Aristotle.[59] The encounter of the future "ruler of the world" with one of the most famous philosophers and intellectuals of Greece is, as Krzysztof Nawotka observes, virtually ideal material for a legend $[60]$ - one which began with Plutarch. The Greek presents the circumstances which brought Aristotle to the court in Pella. This was Philip's doing; after having noticed the tenacious and proud nature of the boy, he decided that conversation would be more effective than coercion. He came to the conclusion that not only teachers of music but of other educational subjects and disciplines should mould the character and mind of Alexander, and thus hired Aristotle.[61] With much detail, the Chaeronean describes the place of Alexander's education, Mieza, located south-west of Pella, a locality already legendary in Plutarch's times. As he writes, it was a place dedicated to the Nymphs, with stone benches and shaded galleries.[62] Subsequently, Plutarch describes the scope of Alexander's education, which included ethics, politics, and acromatic and epoptic knowledge.[63]

Plutarch also writes at length about Alexander's medical education, including both theory and practice, which he received in Mieza as well. He observes furthermore that Aristotle gave him a revised copy of Homer's Iliad, which, as Plutarch emphasizes, he always kept with him.[64]

[55] Plutarch, Alexander 1.

[56] K. Nawotka, Aleksander, p. 66.

[57] Plutarch, Alexander 25; K. Nawotka, Aleksander, p. 67.

[58] Ibid. 5; K. Nawotka, Aleksander, pp. 66-67.

[59] Plutarch, Alexander 7-8; K. Nawotka, Aleksander, pp. 70-74.

[60] K. Nawotka, Aleksander, p. 71.

[61] Ibid., p. 66.
[62] Plutarch, Alexander 7; P. Green, Aleksander, p. 63.

[63] Plutarch, Alexander 7; K. Nawotka, Aleksander,

p. 72.

[64] Plutarch, Alexander 8.1-2: "He was also by nature a lover of learning and a lover of reading. And since he thought and called the Iliad a viaticum of the military art, he took with him Aristotle's recension of the poem, called the Iliad of the Casket, and always kept it lying with his dagger under his pillow, as 
Plutarch informs that Homer was Alexander's favourite author. The Macedonian tried to equal Homer's protagonists, especially Achilles. Plutarch also observes that Alexander was well read in literature; he knew the works of Philistos, a $4^{\text {th }}$-century BC historian from Sicily, the tragedies of Euripides, Sophocles, and Aeschylus, and the dithyrambs of Telestes and Philocles.[65] Plutarch's text permits us to surmise that Alexander's education was something his parents were genuinely concerned about, and that most of his studies coincided with his school years.[66] Plutarch notes that the relationship between Aristotle and Alexander, based on the principle of master and disciple, grew weaker with time, eventually leading to distrust.[67]

The most famous episode from Alexander's childhood, illustrating his ability to submit others, both humans and animals, to his will was his taming of the horse Bucephalus. Plutarch describes in detail the moment of his curbing the black Thessalian steed. He describes the location, an open field, and presents the protagonists, Philip and Philonikos, who brought Bucephalus to Philip and Alexander. He notes that the event was a public one. The fact that Alexander noticed that Bucephalus was afraid of the sun demonstrates the intelligence of the future ruler of Macedonia. [68] He also quotes dialogues between Philip and Alexander, [69] in which the latter proves himself to be confident, determined, and capable of taking a risk.

For boys from ruling families, reaching the age of 16 meant the beginning of adulthood, and being entrusted with first significant tasks relating to the state.[70] Plutarch writes that Alexander turned 16 just as Philip was setting out for his expedition against Byzantium, and left his son in Macedonia as regent, entrusting him with its affairs and the royal seal.[71]

Plutarch describes the relationships between Olympias and Philip II in the context of assuming the regency. He states unequivocally that the amorous relationships of Philip with other women were a cause of domestic friction.[72] At the same time, he observes that the root cause was the difficult temperament of Olympias, who was a jealous and headstrong woman. [73] Plutarch observes: "She spurred Alexander on." [74]

Like Plutarch, Robert Rossen omitted themes relating to Alexander's childhood; after showing his babyhood, he passes over to his

Onesicritus informs us"; P. Green, Aleksander, p. 68;

K. Nawotka, Aleksander, p. 72.

[65] Plutarch, Alexander 8; K. Nawotka, Aleksander, p. 67.

[66] K. Nawotka, Aleksander, p. 67.

[67] Plutarch, Alexander 8.3: „Aristotle he admired at the first, and loved him, as he himself used to say, more than he did his father, for that the one had given him life, but the other had taught him a noble life; later, however, he held him in more or less of suspicion."

[68] Plutarch, Alexander 6.
[69] P. Green, Aleksander, pp. 53-55.

[70] K. Nawotka, Aleksander, pp. 82-83.

[71] Plutarch, Alexander 9.1: "While Philip was making an expedition against Byzantium, Alexander, though only sixteen years of age, was left behind as regent in Macedonia and keeper of the royal seal."

[72] Plutarch, Alexander 9.

[73] Ibid. 9.3: "the bad temper of Olympias, who was a jealous and sullen woman, made still greater."

[74] Plutarch, Alexander 9.4; E.D. Carney, op. cit., p. 138 . 
adolescence, showing the teenage Alexander meeting with Aristotle in the gymnasium, as he allows the viewer to infer, or more precisely, the palaestra. Their conversation takes place against the backdrop of exercising wrestlers and boxers. Here we are introduced to Cleitus the Black, brother of Lanike, Alexander's wet nurse. Nawotka supposes that Cleitus might have also been taught by Aristotle in Mieza.[75] In this long dialogue, Rossen uses the character of Aristotle to recount a historic moment, i.e. Philip's plans through the lands of Persia, and shows the unyielding character of Alexander, who rejects the wonders of science, mathematics, history, and logic in favour of the pursuit of glory. A later conversation between Aristotle and Alexander concerns the project of uniting the Greeks and Macedonians, the plan of conquering Persia, and the nature of Philip's rule. In Rossen, Aristotle develops an awareness of leadership in Alexander. He observes that Philip II as a ruler is reluctantly approached by the Greeks. The Starigite concludes that Alexander is the one who could rule the Persian Empire. At the same time, he asks him to be patient. Alexander is far from it, obsessed as he is with the quick conquest of Persia. Philip's son quotes Achilles who, faced with the choice between a peaceful and glorious life, chose glory. Subsequently, Rossen shows Aristotle delivering an exalted speech - a disquisition on civilizational/cultural differences between the Greeks, Barbarians, and Persians - and Alexander passionately reading out a fragment of Homer's Iliad about the valour of Achilles. He also shows the physical training of Alexander, including wrestling, javelin throwing, and sword fighting.

A conversation follows between Aristotle and Philip concerning Alexander's assumption of rule in Pella, which veers from this subject to the rivalry between Olympias and Philip, who are vying for their son's affections. Additionally, we learn from Philip that Alexander's education had taken place in Mieza. Alexander's education is the final theme addressed by Aristotle.

Subsequently, the plot moves to Pella. In successive dialogue scenes, Rossen illustrates the relations between Alexander and Olympias. As Olympias talks to Alexander, we learn about conspiracies against Philip in Pella in which Olympias herself was to be involved, about the planned nuptials of Philip with the niece of Attalus, and about Olympias' plans for joint rule with Alexander. In turn, Philip returns to the issue of conspiracies, for which he blames Olympias. He orders Alexander to banish Olympias, while the angry Alexander leaves Philip saying that he will join his mother.

Rossen subsequently shows how Alexander received his first tasks of state importance, when his father entrusted him with the regency of Macedonia during his absence. The director focuses on two issues: the handing over of the royal seal and the rivalry between Philip and Olympias. With Olympias listening in the background, Philip 
utters the following words to Alexander: "Don't trust anybody"; we also learn that the actions of the young regent were supervised and supported by Antipater.

In Stone's film, Alexander's youth is devoted to developing his personality and friendships. The plot moves to the palestra, where wrestling training takes place, during which Alexander's closest associates, Hephaestion, Cassander, and Ptolemy, are introduced. Stone shows how, under the guidance of a strict tutor, Alexander's character is moulded, namely his courage and dedication. He then takes the viewer to Aristotle's school. There, in the retreat of a portico, he shows young Alexander surrounded by his closest ones, acquiring knowledge of geopolitics, and learning about the cultural superiority of Greeks over the Persian Empire. Alexander polemicizes with Aristotle regarding mythical heroes, including Heracles, Dionysus, Theseus, Jason, and Achilles. Stone thus shows the rationality which is developing in Alexander, whose thoughts are dominated by the idea of ruling over the Persians. During the lecture, there recurs the theme of love between Achilles and Patroclus. The narrator, Ptolemy, provides additional information, adding that Philip II brought Aristotle to teach the Macedonians, as he was planning an expedition against Persia.

The taming of Bucephalus is also depicted in Stone's film. The event takes place in an open-air setting. The American director shows the tenacity of the animal, the surrender of Philip's companions, Philip's resignation, and the courage of Alexander. Stone lends a visual dimension to the dramaturgy concealed in Plutarch's words. He includes number of details: the shadow frightening the horse, the reaction of the crowds, and the dynamism of Bucephalus's gallop. The scene ends with an illustration of Philip's pride over his son's success. Simultaneously, Stone introduces an important character in the film, Olympias. He shows the relationship connecting Olympias and Alexander, as well as her fear of losing her position as Philip's main wife and queen.

Stone concludes the tale of Alexander's youth with a conversation between Philip and Alexander, which takes place in a cave, in semi-darkness, against the backdrop of cave paintings. The latter, as well as the conversation itself, are related to mythological themes. The myths of Achilles and Patroclus, Prometheus, Heracles, Oedipus, Medea, and Jason are invoked again. The dominant subject is the rivalry between the father and the mother, as well as the loneliness it entails. Undoubtedly, the scene is an expression of the director's creative freedom. It follows the dramaturgical thread of the film, showing how the personality of the future conqueror of Persia was moulded against the background of conflict between Olympias and Philip II.

The authors confess that our article focuses only on the issue of legends and sound historical facts that surround the conception, birth, childhood, and the formative period of the early youth of the great Macedonian hero, warrior, and "King among kings/King of kings" as his newly conquered Persian subjects half-heartedly saw him and 
even more their distant Islamic mediaeval descendants in Iran saw him as a true "King of kings." This period, beginning with Alexander's conception and birth and ending in the sixteenth year of his short and glory-filled life, encompasses many of the constituent elements of the future myth of Alexander the Great: son of Zeus-Amun, the god of Siwah, but also son of Philip II of Macedon and Olympias, the fiery Epirote princess; descendant of Heracles and Achilles; King of Macedon; Leader of the Greeks; "Lord of the Two Lands" (the Lower and the Upper Egypt) i.e. "Pharaoh of Egypt"; "King of Asia"; and self-proclaimed King of Persia by right of conquest, a claim never fully accepted by his Persian subjects during his lifetime, but full-heartedly assumed by their distant Islamic descendants after the Arab-Muslim conquest of Sassanid Persia in the middle of the $7^{\text {th }}$ century AD. [76]

Conclusion

There is no doubt that works written while Alexander was still alive - those portraying his deeds - were not true to life. However, they forged the legend of a great conqueror of Persia, thus becoming the foundation of lore about Alexander the Great. Undoubtedly, Alexander the Great by Robert Rossen, and Oliver Stone's Alexander perpetuate the legend of a civilisation-bringing founder of a great Empire. They dazzle with panache, with the splendour of their costumes, set design, and star-studded cast. These are an expression of a yearning for a living legend. Without doubt, both films are epic works in scale, mega-productions for the times in which they were made. In their cinematic frescoes, both Rossen and Stone enhanced the topos of Alexander's biography: Alexander growing up among the rivalry between Philip and Olympias, Alexander the son of a god, Alexander the disciple of Aristotle, and Alexander pursuing the myth of Achilles.[77]

In both Rossen's and Stone's films, Alexander's life is given a dramatic structure: its episodes are arranged along the prominent line of the conflict between the calling of the protagonist and his social and political surroundings. The conflict in question is that between Philip and Olympias, while his mission is the conquest of the world and the pursuit of glory. Both Rossen and Stone introduce Plutarch's work into this dramatic paradigm. The former focuses on the facts, showing the background to events and explaining the causes of historical transformations. Rossen's Alexander the Great is thus a visual historical study, more akin to a historiographic narrative. In Stone's view, Rossen spends too much time on Alexander's early years in Macedon.[78] Those elements from Plutarch's work which make it possible to show the background to Alexander the Great's biography are subordinated to that very concept. Oliver Stone, in turn, by making Ptolemy the narrator, brings the ancient sources to life. At the same time, he indicates that the narrative will be a subjective one. Stone's Alexander is a film about 
emotions. [79] Clearly playing on Plutarch's statement [80] that he "wrote lives not history," Stone has said that he makes "film not history." [81] In depicting scenes from Alexander's youth which were recorded in history, Stone, like Plutarch, assumes the role of a painter, giving Alexander a psychological dimension. He conveys onto the screen the dramaturgy hidden in Plutarch's words. Stone's work thus represents a kind of return to the sources, an attempt to read them anew. 